\title{
Impact of Populus Plantations on Water and Soil Quality
}

\author{
Ioannis Dimitriou ${ }^{1} \cdot$ Blas Mola-Yudego $^{2,3}$
}

Published online: 24 May 2017

(C) The Author(s) 2017. This article is an open access publication

\begin{abstract}
Trees of genus Populus (in our context primarily poplars) are predominantly grown in Sweden in small plantations on arable land in southern and central parts of the country to produce biomass for energy and other purposes. This study evaluated the effects (i) of poplar plantations on groundwater quality, by determining differences in leaching of nitrogen and phosphorus to groundwater, and (ii) of poplar and hybrid aspen plantations on soil quality in terms of carbon in the top- and subsoil. The study was conducted comparing Populus plantations in Sweden with adjacent fields with cereals and grasslands. The experiment concerning the groundwater leaching was conducted in eight poplar plantations along three growing seasons (2012-2015). For the soil carbon experiments, 19 poplar and two hybrid aspen plantations and the respective reference fields were sampled. $\mathrm{NO}_{3}-\mathrm{N}$ leaching from poplar plantations was significantly lower than that from reference fields with cereals, but not when compared with grasslands. Spring $\mathrm{NO}_{3}-\mathrm{N}$ leaching was significantly lower in poplars than in the reference fields, whereas leaching of $\mathrm{NO}_{3}-\mathrm{N}$ in autumn did not differ. Concentrations of $\mathrm{PO}_{4}-\mathrm{P}$ in the groundwater of poplar plantations were lower compared to the respective ones of the reference fields. There were no clear trends observed when comparing carbon concentrations in the
\end{abstract}

Ioannis Dimitriou

ioannis.dimitriou@slu.se

1 Department of Crop Production Ecology, Swedish University of Agricultural Sciences (SLU), P.O. Box 7016, S-750

07 Uppsala, Sweden

2 School of Forest Sciences, University of Eastern Finland, PO Box 111, 80101 Joensuu, Finland

3 Norwegian Institute of Bioeconomy Research (NIBIO), P.O. Box, 115,1431 Ås, Norway topsoil of the poplar and hybrid aspen plantations compared to the respective adjacent reference fields. For the subsoil, the average carbon concentrations in the poplar and hybrid aspen plantations were equal to the respective ones of cereals, but were higher when compared to grassland.

Keywords Bioenergy · Biomass · Nitrate leaching · Phosphorus leaching $\cdot$ Poplar $\cdot$ Soil carbon

\section{Introduction}

Trees of genus Populus (in our context, we primarily refer to poplars and secondly to hybrid aspens) are predominantly grown in Sweden in small plantations on arable land in southern and central parts of the country to produce biomass for energy and other industrial purposes. In the 1980s and 1990s, many plantations were established on small areas of set-aside agricultural land, mainly for demonstration purposes and to assess their productivity. During that period, the most frequent poplar clones planted were OP 42 (Prunus maximowiczii Henry $\times$ Populus trichocarpa Torr. and Gray), followed by balsam poplar ( $P$. balsamifera L.), and black cottonwood (P. trichocarpa). However, in recent years, the growing demand for biomass for energy in Sweden has increased the interest in poplars and other fast-growing lignocellulosic species suitable for short rotations [1]. Although still limited in extension planted, about 1744 ha of Populus plantations in Sweden in 2014 entails 1322 ha of poplar and 422 ha of hybrid aspen plantations [2].

In addition to their use as a biomass production system, these type of fast-growing plantations present potential advantages for environmental and ecosystem services. Extensive research has already been conducted to estimate the environmental performance of fast-growing tree species such as 
willows grown as short rotation coppice under controlled conditions [3,4], in commercial fields to assess groundwater and soil quality (e.g., as in [5, 6]) or based on life cycle assessment (e.g., as in [7, 8]). However, similar studies for poplars are scarce in Nordic conditions due to their limited area planted and their more recent establishment as a viable biomass production system for energy. It has been suggested that poplar plantations can perform comparably to willows in terms of nitrogen leaching when well established [3]. In fact, it has been reported that poplars grown for several years showed significantly reduced nitrate concentrations in their groundwater even compared to willow fields of similar management [9]. Despite indications that poplars can present reduced leaching in the groundwater in large-scale plantations retaining high amounts of nitrogen in the soil-plant system, extensive research on this issue is missing.

At the same time, there have been indications that leaching of phosphates from willow short rotation coppice is equal or higher than from adjacent reference fields [5], although there have been other authors suggesting that willow short rotation coppice reduces the phosphate leaching in agricultural landscapes $[10,11]$. Concerning leaching of phosphates in poplar plantations, research has, yet again, been rather limited; no phosphorus leaching when wastewater and sludge was applied to poplars grown in clay-soil lysimeters [3], and very low leaching via drainage water from sand-soil lysimeters. However, patterns of phosphorus leaching are usually difficult to predict and are dependent on several factors $[12,13]$ and this raises some uncertainty on phosphorus leaching from poplar fields, especially when compared with other arable fields in the area.

Several authors have indicated that establishing poplar plantations grown in short rotations could be a means to increase carbon in the soils of agricultural landscapes [14-18], replacing therefore common agricultural crops with the aim to mitigate carbon losses from the soil, and simultaneously produce biomass for energy that will replace fossil fuels. However, there have been other authors suggesting that soil carbon sequestration when poplars are planted in agricultural soils is not always evident [19-21], and that this can depend on a series of factors that are usually site-specific [19, 22, 23]. It has been concluded that the site-specific variability in the effects of SRC on the soil carbon pool is high, that previous studies may not have covered a sufficiently long period to detect significant changes in soil carbon stocks, and that the fundamental mechanisms responsible for soil organic carbon accumulation in poplar plantations are not well understood.

In this paper, we aim at comparing a number of poplar and hybrid aspen plantations grown for a number of years in Sweden with respective reference fields with common agricultural crops (cereals and grassland) adjacent to the plantations, thus having the same soil conditions. The objectives of this study related to water quality are to determine leaching of nitrogen and phosphorus to groundwater of poplar fields in Sweden, and to quantify the differences in nitrogen and phosphorus leaching between these fields and adjacent arable fields grown with conventional crops. Concerning soil carbon, similar comparisons in the top and subsoil are conducted aiming to identify potential differences between the land uses. Our hypotheses were that the $\mathrm{NO}_{3}-\mathrm{N}$ and $\mathrm{PO}_{4}-\mathrm{P}$ concentrations in groundwater in poplar fields would be lower than that from reference fields with ordinary crops, and that soil carbon would be higher both in the topsoil and subsoil of the poplar plantations compared to the reference fields.

\section{Materials and Methods}

\section{Site Description}

In total, 21 locations were investigated (Fig. 1) located in southern (13), western (1), and central-eastern (7) Sweden. For groundwater quality $(N=8)$, only poplar plantations were studied. For the soil samples $(N=21)$, both poplar and hybrid aspen plantations were considered. The plantations were selected so as they (i) were at least 10 years old; (ii) had adjacent arable fields with the same soil texture that could be used as

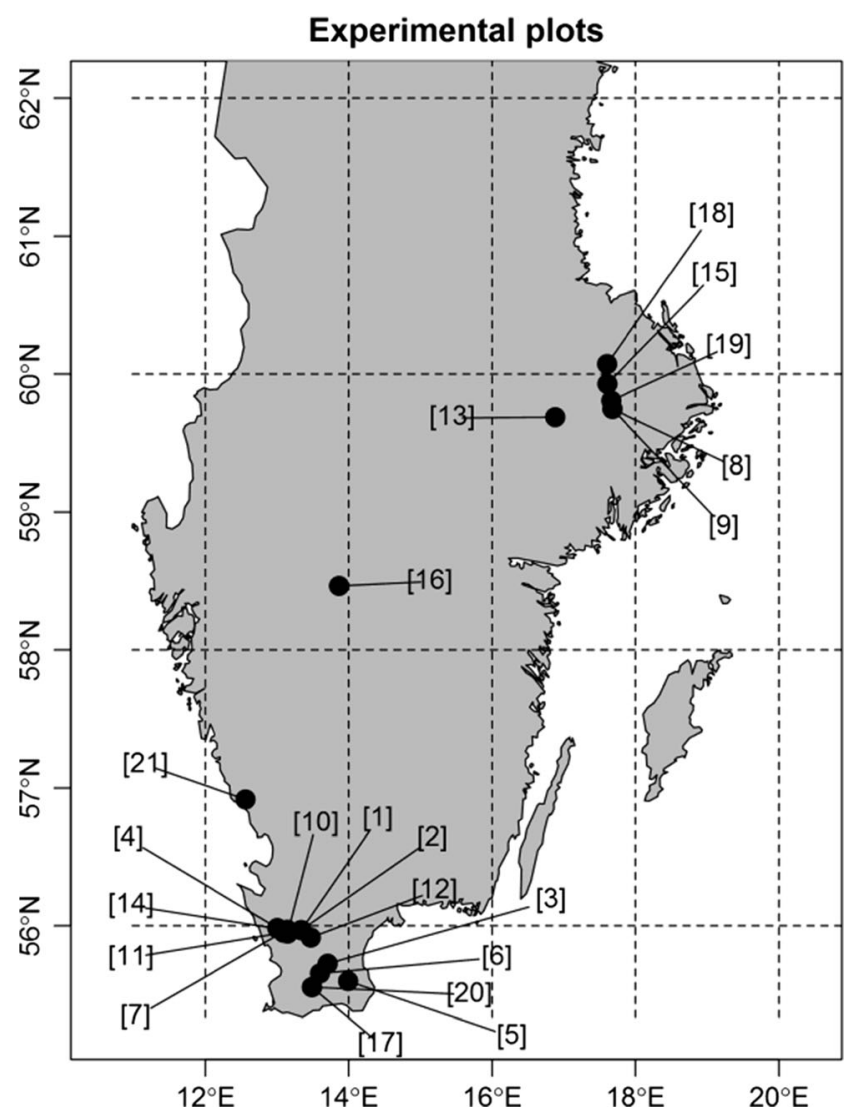

Fig. 1 Location of the poplar plantations where trials were established in central and south Sweden (the respective numbers indicate the fields included in Table 1) 
reference; and (iii) were located at flat areas that could be used for establishing groundwater pipes at the same ground level as for the reference fields in order to facilitate comparisons. All fields fulfilled the above criteria except for field located at Stöpen (field 16) which had younger plants with very good growth (Table 1). No poplar field included in our experiments was fertilized. In the case of reference fields, fertilization followed standard practices. In the case of grasslands, no fertilization had been conducted; however, in Billinge, the only possible reference field in the area that we could establish a groundwater pipe was a grassland used for feeding horses. In the case of cereals, the common fertilization recommendations had been followed (120-140 kg N ha ${ }^{-1}$ for average yields, 10 $20 \mathrm{~kg} \mathrm{P} \mathrm{ha}{ }^{-1}$ depending on soil $\mathrm{P}$ status, and $0-10 \mathrm{~kg}$ potassium $(\mathrm{K}))$ [29]. A typical crop-rotation cycle had been followed throughout all years.

\section{Sampling and Analyses}

Three groundwater pipes were installed at each poplar field and one in their reference fields in spring 2012. In total, 32 groundwater pipes were installed: 24 in poplar fields located near the field border adjacent to the respective reference field and 8 in reference fields (in places that would not disturb farming mechanical activities, mainly close to field edges near the poplar field when possible or near drainage wells). Holes were drilled down to the groundwater table using an auger. The average depth for the pipes in the different fields was $1.5 \mathrm{~m}$. In all locations, the pipe length in poplars and in respective reference fields was nearly the same.

PVC pipes with $50 \mathrm{~mm}$ diameter and with slits up to $0.5 \mathrm{~m}$ from the bottom were installed in the holes. To prevent clogging with soil particles, the base of each pipe was covered with a fiber cloth up to the slits. The holes were then filled with gravel followed by granulated bentonite clay to prevent short-cut flow of water along the pipe wall. Finally, at the top, a 110-mm PVC pipe with a cap was installed around each pipe to prevent contamination. Samples for chemical analyses were taken using a manual vacuum pump. Before sampling, the groundwater pipes were evacuated, and then a 100-ml sample of fresh groundwater was collected in a plastic jar. Sampling was conducted according to other studies for groundwater sampling for assessing leaching [3], since on structured clayey soils, hardly any other useful non-destructive method to estimate leaching in a field situation exists. Sampling was planned to be conducted from spring 2012 to summer 2015 on a regular basis. The samples were taken once a month, approximately around the same period in all the sites; however, in

Table 1 Description of the different locations where groundwater pipes were established (marked *) and soil sampling occurred. OP 42 is a cross of P. maximowiczii $x$ P. trichocarpa

\begin{tabular}{|c|c|c|c|c|c|c|c|c|c|}
\hline ID & Location & LAT & LONG & Planted & Age & Reference & Species/clone & Soil type & Est. yield \\
\hline 1 & Billinge I $(*)$ & 55.97 & 13.34 & 2002 & 13 & Grass & OP 42 & Sand & 8.15 (est) \\
\hline 2 & Billinge II & 55.97 & 13.34 & 1991 & 24 & Grass & OP 42 & Sand & 10.10 (est) \\
\hline 3 & Bjärsjölagård (*) & 55.72 & 13.71 & 1988 & 27 & Cereals & P. balsamifera & Light clay & $14.03[24]$ \\
\hline 4 & Bullstofta & 55.98 & 13.01 & 1993 & 22 & Cereals & P. boelare & Sand & $7.9-9.2[25]$ \\
\hline 5 & Helenedal & 55.60 & 13.99 & 1989 & 26 & Cereals & Mixture & Sandy silty & \\
\hline 6 & Karinslund & 55.65 & 13.60 & 1990 & 25 & Grass & OP 42 & Sand & 10.10 (est) \\
\hline 7 & Knutstorp & 55.97 & 13.14 & 1990 & 25 & Grass & OP 42 & Light clay tills & $6.97[24]$ \\
\hline 8 & Krusenberg I $(*)$ & 59.75 & 17.68 & 2003 & 12 & Grass & P. trichocarpa & Light clay & 7.58 (est) \\
\hline 9 & Krusenberg II (*) & 59.75 & 17.68 & 2003 & 12 & Grass & P. trichocarpa & Light clay & 10.74 (est) \\
\hline 10 & Källstorp & 55.94 & 13.15 & 1990 & 25 & Cereals & P. tremula $\times P$. tremuloides & Clay moraine & \\
\hline 11 & Lönnstorp & 55.95 & 13.10 & 1988 & 27 & Cereals & P. tremula $\times$ P. tremuloides & Light clay tills & \\
\hline 12 & Ormanäs & 55.91 & 13.47 & 1995 & 20 & Grass & Mixture & & \\
\hline 13 & Petersberg $(*)$ & 59.69 & 16.88 & 1991 & 24 & Rapeseed & P. balsamifera & Light clay & $6.04-7.45$ (est) \\
\hline 14 & Sofielund & 55.98 & 13.01 & 1991 & 24 & Rapeseed & OP 42 & Sandy-silty tills & \\
\hline 15 & St.Vallskog $(*)$ & 59.93 & 17.61 & 1991 & 24 & Rapeseed & P. angustifolium & Silt & 6.55 (est) \\
\hline 16 & Stöpen & 58.46 & 13.87 & 2006 & 9 & Cereals & OP 42 & Light clay & $3.64-8.09$ (est) \\
\hline 17 & Sunnersta & 59.81 & 17.66 & 1991 & 24 & Cereals & P. trichocarpa & Light clay & 1.96 (est) \\
\hline 18 & Sångletorp I (*) & 55.55 & 13.49 & 1991 & 24 & Cereals & OP 42 & Sandy loam & 6.6 (est) \\
\hline 19 & Sångletorp II & 55.55 & 13.49 & 1991 & 24 & Rapeseed & OP 42 & Sandy loam & 8.5 (est) \\
\hline 20 & Sätuna (*) & 60.07 & 17.60 & 1990 & 25 & Cereals & OP 42 & Light clay & $9.89-18.67$ (est) \\
\hline 21 & Tröingeberg & 56.92 & 12.55 & 2006 & 9 & Cereals & & & \\
\hline
\end{tabular}

Est. yield Estimated yield (odt ha ${ }^{-1}$ year $^{-1}$ ) according to own measurements (est, see [2-23, 26] for methods) and other sources [27, 28] 
Fig. 2 Differences in $\mathrm{NO}_{3}-\mathrm{N}$ and $\mathrm{PO}_{4}-\mathrm{P}$ concentrations $(\mathrm{mg} / \mathrm{l})$ in the groundwater of poplar plantations and reference crops. The boxes represent the upper and lower quartile, the bands, and the upper and lower $10 \%$, and the central line corresponds to the median (boxplot). Concentrations are shown in logarithmic scale
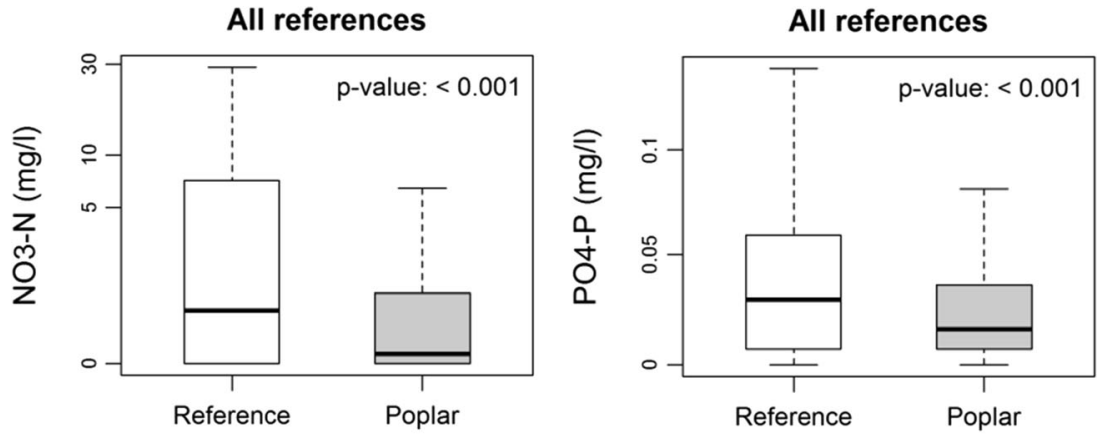

Cereal
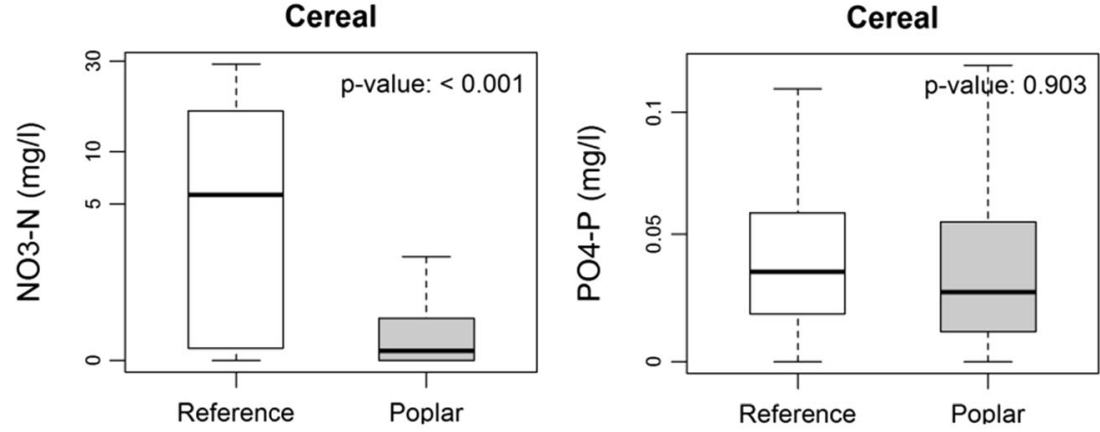

Grass

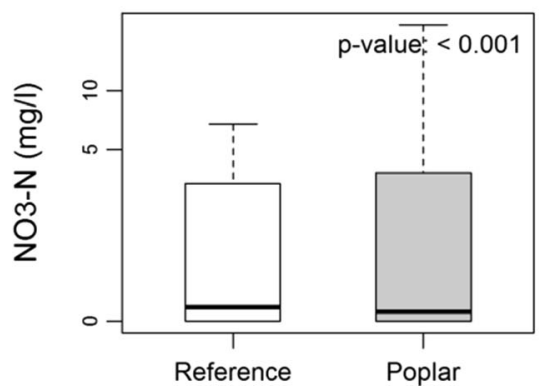

some cases, there was no water available in the pipes, and on the other hand, the sampling was intensified during autumn and snow-melting periods when extensive drainage was assumed. In total, 436 measurements were taken $(109 \times 4)$. All collected samples were analyzed for $\mathrm{NO}_{3}-\mathrm{N}$ and $\mathrm{PO}_{4}-\mathrm{P}$. The analytical methods for nitrogen were according to the Swedish standard SS02813. For phosphorus, the SS-EN ISO 6878:2005 was used. All phospectrometric measurements were performed using the system Konelab Aqua 60.

Concerning the soil analysis, samples of topsoil $(0-20 \mathrm{~cm})$ and subsoil $(40-60 \mathrm{~cm})$ were taken from all 21 poplar and hybrid aspen fields and their reference fields. Three samples were taken in the poplar/aspen plantation matching three samples in the reference field, in both cases ca. 5-10 $\mathrm{m}$ from the border of the field and with a distance of ca. $15 \mathrm{~m}$ between sampled spots, resulting on 252 measurements. Each topsoil sample consisted of six pooled subsamples taken within a circle with a radius of two meters. In the subsoil sampling, four subsamples were pooled together into one.

The samples were dried at $30-40{ }^{\circ} \mathrm{C}$ until constant weight. Total carbon was measured on an elemental analyzer (LECO
$\mathrm{CH}-2000$ ) where $1 \mathrm{~g}$ of sample was heated to $1250{ }^{\circ} \mathrm{C}$ for $5 \mathrm{~h}$. The soil texture was not determined in the lab, but existing information from the land owners and previous experiments was used.

\section{Statistical Analyses}

The analysis for differences between reference plots and poplar for $\mathrm{NO}_{3}-\mathrm{N}$ and $\mathrm{PO}_{4}-\mathrm{P}$ concentrations were presented using boxplots, representing the median as well as the higher and lower quartiles, which allows better description of the distribution followed by the data. Comparisons were established for groundwater and soil quality records, including any potential seasonal effects between spring and autumn. Due to the hierarchical structure of the measurements, aggregated by plantation, a mixed model approach was taken in which a fixed effect (the overall differences between poplar plantations and reference fields) was combined to a random effect representing the individual plantation, as a grouping level, thus discriminating between-sites variability from betweenmeasurements variability within the same site and addressing 
the potential auto-correlation of the data. The generalized mixed models followed the general structure:

$y_{i j}=\beta_{0}+\beta_{1} \cdot$ poplar $+\cdots+\mu_{i}+\mu_{i j}$

where $y$ is the dependent variable related to the concentrations in site $i$, poplar is a dummy variable that is 1 when the measurement is on a poplar plantations and 0 otherwise, $\mu_{i}$ is the between-site random factor, and $\mu_{i j}$ is the final error term (measurement $j$ on site $i$ ). Therefore, the $p$ value of the $\beta_{1}$ was used to assess differences between poplar plantations and reference plots, and the significance of this parameter was set at the 0.05 level. Model variations were constructed to test for seasonal differences. For the $\mathrm{NO}_{3}-\mathrm{N}$ and $\mathrm{PO}_{4}-\mathrm{P}$ concentrations on water, the dependent variable presented a non-normal distribution including many zero values. To accommodate this data structure, the models were based on a Poisson distribution, using the $\log$ link function. For the soil carbon, the dependent variable was treated as a percentage that presents a minimum and a maximum threshold ( 0 to $100 \%$, respectively). In this case, the dependent was normalized using the logit transformation, following:

$\operatorname{logit} \mathrm{C}=\ln \left(\frac{c}{1-c}\right)$

where $c$ are the measured carbon concentrations in soil. Since there were no observations with the exact threshold values $(0$ or $100 \%$ ), no further transformations were needed, the data was treated assuming normal distribution, and the $p$ values of the parameters of the fixed part of the models were established using a $t$ value. Finally, comparisons were established between the plantations' measured concentrations of $\mathrm{NO}_{3}-\mathrm{N}, \mathrm{PO}_{4}-\mathrm{P}$, and Carbon and their respective yields. The calculations were based on the package nlme [24] and lme 4 [25] in the R version 3.2.0 [30].

\section{Results}

The reference plots showed higher $\mathrm{NO}_{3}-\mathrm{N}$ concentrations in the groundwater than in poplar plantations, which was significant both when cereals and grasslands were used for reference. In the case of cereals, the $\mathrm{NO}_{3}-\mathrm{N}$ was particularly high, nearly five times higher median concentrations than in the case of poplar fields. Concerning $\mathrm{PO}_{4}-\mathrm{P}$, the concentrations were also lower in poplar fields, although these differences were only significant when using grasslands as reference fields (Fig. 2). These averages entail the whole experimental period (spring 2012-spring 2015). These differences were consistent along seasons: in the case of $\mathrm{NO}_{3}-\mathrm{N}$ in both seasons, and in the case of $\mathrm{PO}_{4}-\mathrm{P}$ only in autumn (Fig. 3), according to the generalized mixed models applied (Table 2).
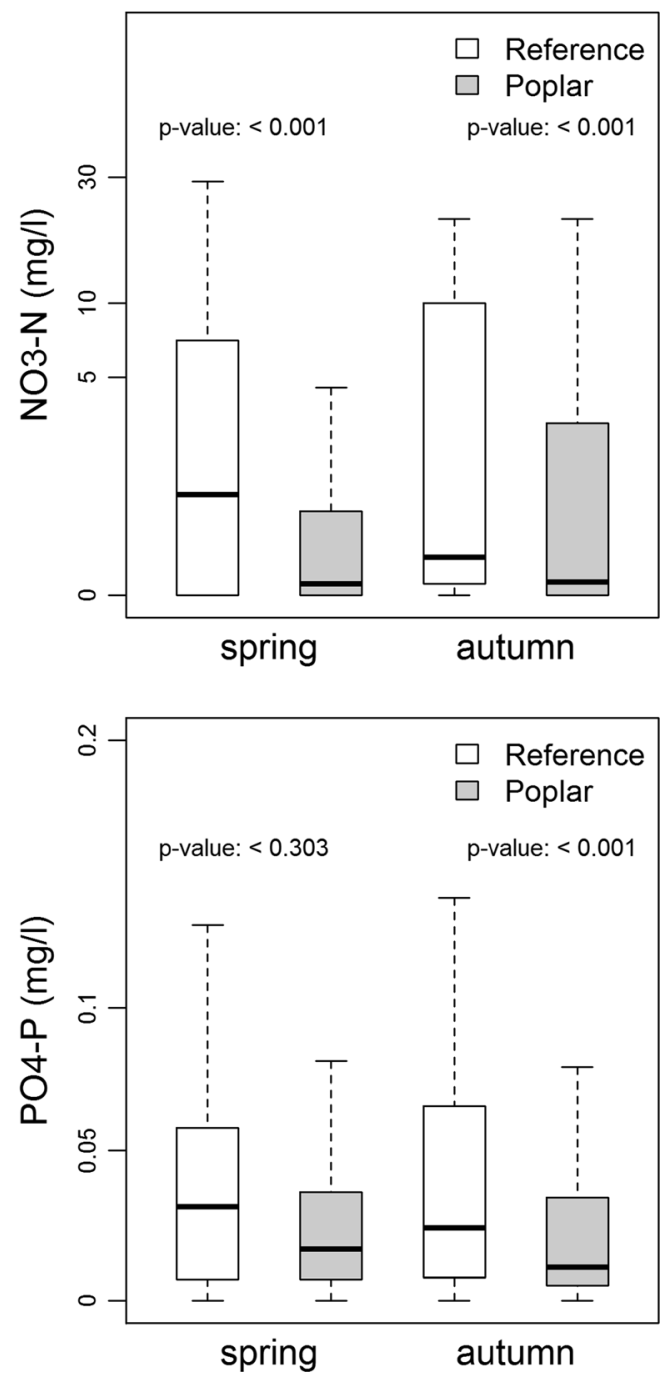

Fig. 3 Averages of $\mathrm{NO}_{3}-\mathrm{N}$ and $\mathrm{PO}_{4}-\mathrm{P}$ concentrations in the groundwater of all poplar plantations and reference fields during spring (March until June) and autumn (September until December). The boxes represent the upper and lower quartile, the bands, and the upper and lower $10 \%$, and the central line corresponds to the median (boxplot). Concentrations are shown in logarithmic scale

The $\mathrm{NO}_{3}-\mathrm{N}$ concentrations in the groundwater were in general higher in cereal plots except for the Sätuna trial (Sätu), with particularly large differences in Bjärsjölagård (Bjär) and Sångletrop (Sång). $\mathrm{NO}_{3}-\mathrm{N}$ concentrations were however lower in the groundwater of the references located at Billinge (Bill) which was located on grasslands. Concerning $\mathrm{PO}_{4}-\mathrm{P}$, there were no clear trends, as each trial presented opposite trends; concentrations were lower in the references at Billinge (Bill) and Krusenberg 1 (Krul), and higher in Krusenberg 2 (Kru2) and Sångletrop (Sång) (Fig. 4).

Concerning soil carbon, in the topsoil, the average concentrations of soil organic carbon were similar to the reference fields ( $p$ value $=0.085, t=1.738$, indicating no significant differences), either when cereals ( $p$ value $=$ 
Table 2 Results of the statistical analysis for groundwater concentrations of $\mathrm{NO}_{3}-\mathrm{N}$ and $\mathrm{PO}_{4}-\mathrm{P}$ and soil carbon in poplar plantations and adjacent agricultural fields. The models make use of the logit transformation and are based on a mixed model approach with the field as a grouping factor, and a Poisson distribution for $\mathrm{NO}_{3}-\mathrm{N}$ and $\mathrm{PO}_{4}$ $\mathrm{P}$ and a normal distribution for soil carbon

\begin{tabular}{lllll}
\hline & $\mathrm{NO}_{3}-\mathrm{N}$ & $\mathrm{PO}_{4}-\mathrm{P}$ & $\mathrm{C}$ topsoil & $\mathrm{C}$ subsoil \\
\hline$\beta_{0}$ & 2.714 & -1.111 & -3.743 & -5.229 \\
$\mathrm{SE}$ & $(0.637)$ & $(0.490)$ & $(0.062)$ & $(0.122)$ \\
$p$ value & $<0.001$ & 0.023 & $<0.001$ & $<0.001$ \\
$\beta_{1}$ (poplar) & -1.021 & -0.748 & 0.066 & 0.098 \\
$\mathrm{SE}$ & $(0.020)$ & $(0.199)$ & $(0.038)$ & $(0.836)$ \\
$p$ value & $<0.001$ & $<0.001$ & 0.085 & 0.242 \\
$\sigma_{\text {site }}$ & 1.800 & 1.270 & 0.259 & 0.490 \\
$\beta_{0}$ & 2.722 & -1.610 & & \\
$\mathrm{SE}$ & $(0.641)$ & $(0.535)$ & & \\
$p$ value & $<0.001$ & 0.003 & & \\
$\beta_{1}$ (poplar) & -1.196 & 1.380 & & \\
$\mathrm{SE}$ & 0.023 & 0.312 & & \\
$p$ value & $<0.001$ & $<0.001$ & & \\
$\beta_{2}$ (autumn) & -0.040 & -0.257 & & \\
$\mathrm{SE}$ & $(0.033)$ & $(0.252)$ & & \\
$p$ value & 0.215 & 0.309 & & \\
$\beta_{3}$ (poplar $\times$ autumn) & 0.974 & -1.894 & \\
$\mathrm{SE}$ & $(0.047)$ & $(0.596)$ & & \\
$p$ value & $<0.001$ & 0.001 & & \\
$\sigma_{\text {site }}$ & 1.809 & 1.334 & & \\
\hline & & & & \\
\hline
\end{tabular}

$S E$ Standard error, $\Sigma_{\text {site }}$ refer to the standard deviations of the grouping factor

$0.154, t=1.438)$ or grassland ( $p$ value $=0.336, t=0.975$ ) was used as a reference. Similarly, in the subsoil, there were no differences ( $p$ value $=0.242, t=1.176$ ) although the values were slightly higher than in adjacent grasslands ( $p$ value $=0.057, t=1.968)$. However, the same was not observed when cereals were used as reference ( $p$ value $=$ 0.983, $t=0.021$ ) (Fig. 5).

For the individual fields, no clear trends could be observed concerning soil organic carbon concentrations (Fig. 6). In the topsoil $(0-20 \mathrm{~cm})$, concentrations were higher in poplar plantations at 8 from 13 locations where cereals were the reference and in 3 out of 8 locations where grassland was the reference. In the subsoil (40$60 \mathrm{~cm}$ ), concentrations were higher in poplar in 6 out of 13 locations where cereal was the reference and in 5 out of 8 where grasslands were the reference. Finally, there was no relationship between the concentrations of $\mathrm{NO}_{3}-\mathrm{N}$ and $\mathrm{PO}_{4}-\mathrm{P}$ and the productivity of the plantations studied. In the case of soil carbon concentrations, there was a weak linear correlation ( $p$ value $=0.013, t=2.547$ ) in the topsoil, and no trend regarding the subsoil measurements was found (Fig. 7).
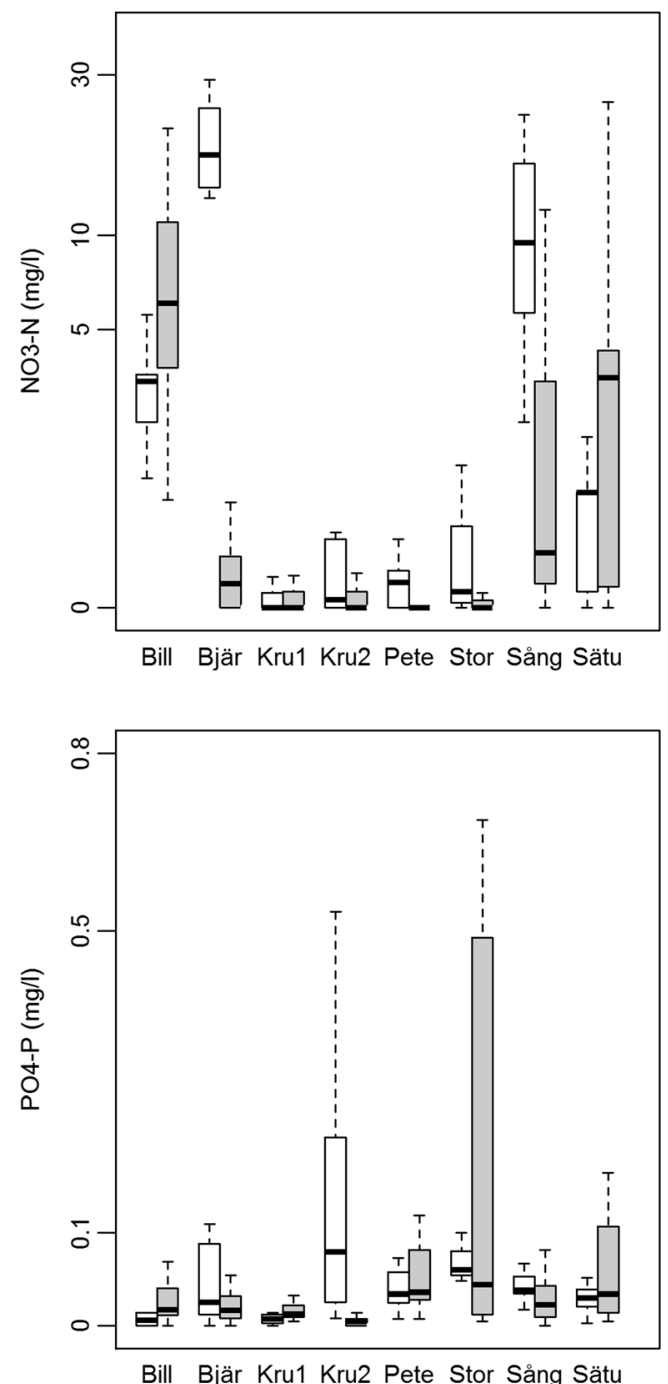

Fig. 4 Median concentrations by field (the labels refer to the initial letters of each of the locations). The boxes represent the upper and lower quartile, the bands, and the upper and lower $10 \%$, and the central line corresponds to the median (boxplot). Concentrations are shown in logarithmic scale

\section{Discussion}

The present study analyzed the groundwater and soil quality of poplar plantations in Sweden, compared to agricultural fields in the same locations. The locations of the sites analyzed were representative of the management practices and areas where poplar is planted in Sweden [2, 27, 28, 31]. The results showed that the $\mathrm{NO}_{3}-\mathrm{N}$ concentrations in the groundwater of poplar fields were lower than in reference fields, with the median from all poplar fields being $0.12 \mathrm{mg} / \mathrm{l}$. These values can be compared with the upper $\mathrm{EU}$ limit for $\mathrm{NO}_{3}-\mathrm{N}$ in groundwater which is equal to $11.3 \mathrm{mg} / \mathrm{l}$, and it is a confirmation of previous results suggesting that $\mathrm{NO}_{3}-\mathrm{N}$ leaching in well-established fast-growing tree plantations is usually lower than in agricultural fields (e.g., for willows [3] and poplars [32]). The low $\mathrm{NO}_{3}-\mathrm{N}$ concentrations are often attributed to 
Fig. 5 Differences in soil carbon (mg/l) at two depth levels (0-20 and 40-60 cm), for poplar plantations and the reference crops. Bars represent the standard error of the means
C $0-20 \mathrm{~cm}$

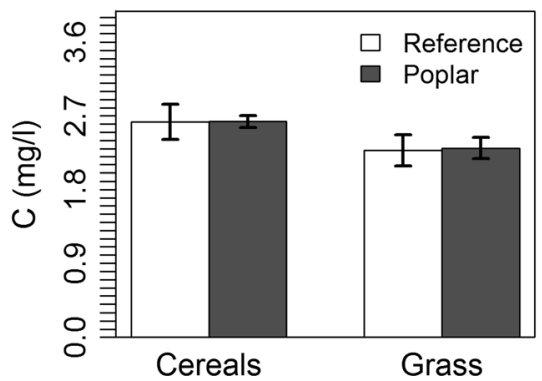

C $40-60 \mathrm{~cm}$

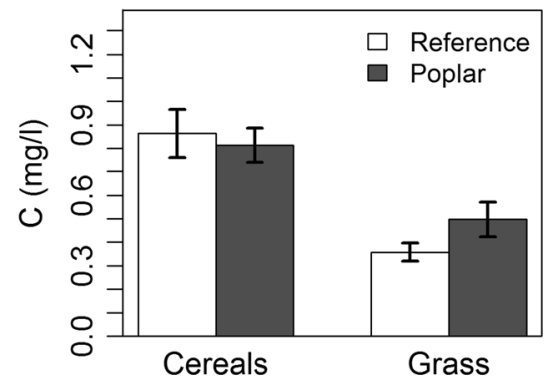

the fact that these plantations are usually not fertilized with nitrogen and to their perennial character, which implies increased nitrogen uptake during the high leaching periods of early spring and late autumn. However, there were two poplar fields (Billinge and Sätuna) where the median of $\mathrm{NO}_{3}-\mathrm{N}$ concentrations in the groundwater throughout the experimental period was higher in poplars than in the reference fields. In Billinge, the grassland was in the lower part of a horse farm where horses were regularly fed with grass, and this could explain the higher concentrations in that field. In the case of Sätuna, the plantations presented a high yield during the former cutting cycles and a large standing volume, but the age of the plantation (ca. 25 years) indicated the current growth rate was low. In addition, the groundwater pipe in the reference cereal field was established in an area surrounded by big stones, which perhaps did not appropriately represented the leached water from the field.
Concerning seasonal peaks, autumn leaching peaks were not avoided when poplars were compared with reference fields, in contrast to spring leaching peaks. This probably means that despite poplars having an established root system, their roots do not remain active late in the autumn period as it has been observed for willow trees in [33]. To limit even more nitrogen leaching in poplar fields, species having root activity in winters should be identified and used. Uninterrupted growth can also be a factor that decreases nitrogen leaching in fast-growing plantations, and therefore, shorter rotations can be expected to have a positive effect on nitrogen leaching.

The differences between $\mathrm{NO}_{3}-\mathrm{N}$ and $\mathrm{PO}_{4}-\mathrm{P}$ concentrations reflect the different mechanisms for leaching in the groundwater: for $\mathrm{NO}_{3}-\mathrm{N}$, it is related to water percolation since $\mathrm{NO}_{3}-$ $\mathrm{N}$ is not bound to the soil particles and is very mobile, whereas $\mathrm{PO}_{4}-\mathrm{P}$ is usually bound to the soil particles therefore having less predictable leaching patterns [34, 35] and its
Fig. 6 Organic carbon in soil from poplar plantations and reference fields (cereal and grasslands) for top soil $(0-20 \mathrm{~cm})$ and deep soil $(40-60 \mathrm{~cm})$
$0-20 \mathrm{~cm}$

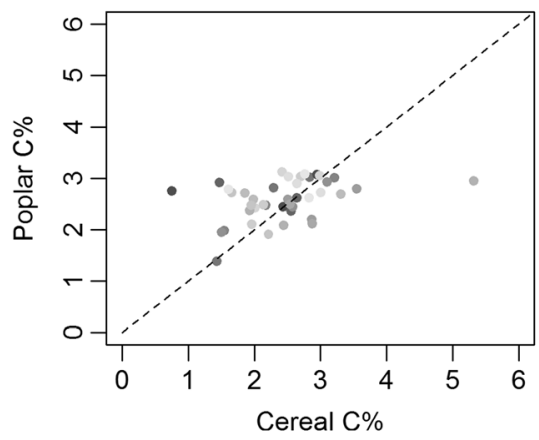

$40-60 \mathrm{~cm}$

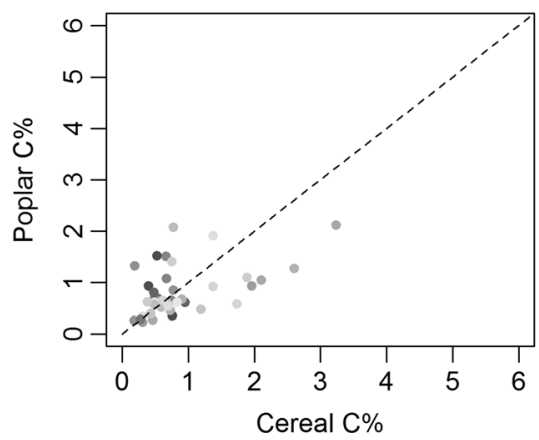

$0-20 \mathrm{~cm}$

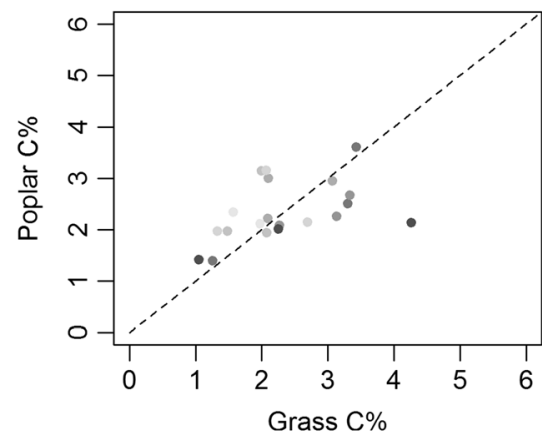

$40-60 \mathrm{~cm}$

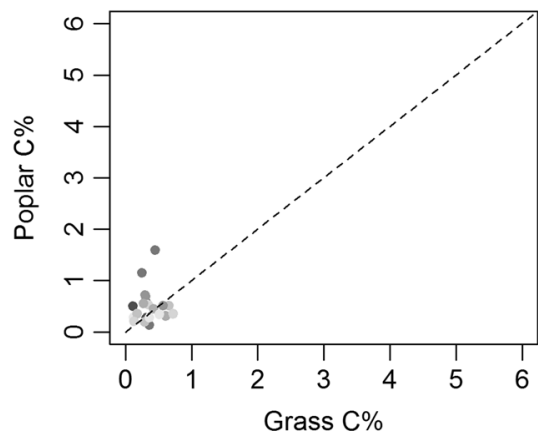


Fig. 7 Concentrations of $\mathrm{NO}_{3}-\mathrm{N}$, $\mathrm{PO}_{4}-\mathrm{P}$, and carbon in top- and subsoil from the poplar plantations investigated, according to their estimated productivity
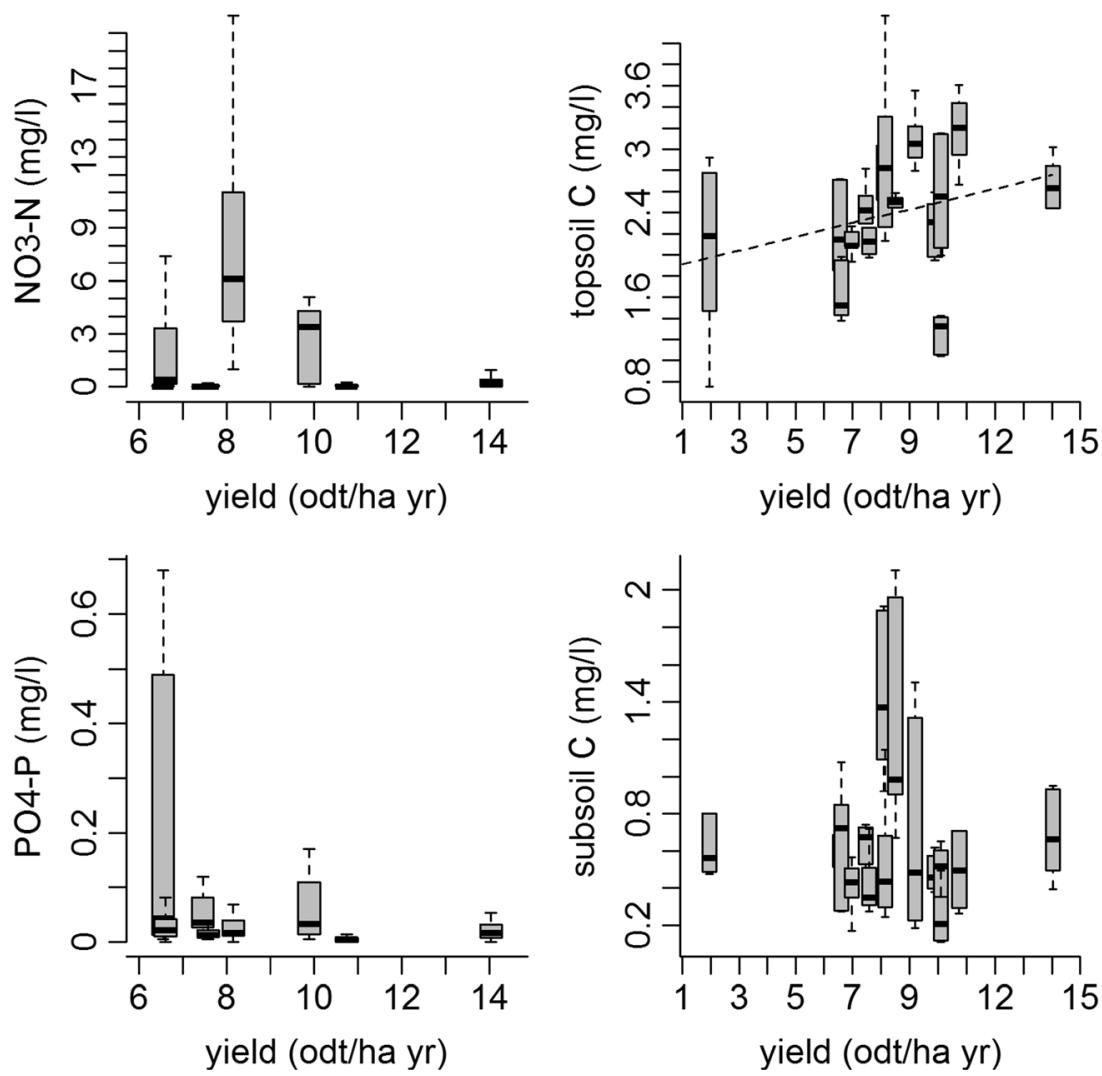

concentrations in the drainage water in actual values are usually much lower than for $\mathrm{NO}_{3}-\mathrm{N}$. This was also depicted in our study, where $\mathrm{NO}_{3}-\mathrm{N}$ concentrations in groundwater were in general considerably higher than these of $\mathrm{PO}_{4}-\mathrm{P}$. $\mathrm{PO}_{4}-\mathrm{P}$ in the groundwater were lower in the poplar plantations compared to both cereals that have been applied with phosphorus via fertilizers, but especially also compared to grasslands that have not been applied with fertilizers. Phosphorus was not applied in the poplar fields, and our results indicate that risk for phosphorus leaching will be limited from such plantations. This agrees with [3] and [11] that have not observed phosphorus leaching from poplars in clay soils in Sweden and in a sandy poplar field in N. Ireland, respectively. In our experiments, most median concentrations in the poplar and reference fields presented very low values (close to $0.1 \mathrm{mg} / \mathrm{l}$ ) and there were no clear trends that could be seen for fields on clay or sand.

We found no differences in the carbon concentrations in the topsoil $(0-20 \mathrm{~cm})$ of poplars both when compared with adjacent fields of cereals or grassland. This does not agree with the predominant belief that growing fast-growing tree species offer elevated carbon amounts in the soil compared to other land uses. In the case of poplars, these come in several cases from results from the field and are not only perceptions. For instance, it was concluded in [15] that hybrid-poplar plantations accreted soil carbon at the rate of $1.6 \mathrm{Mg} \mathrm{ha}^{-1}$ year $^{-1}$ greater than other land uses, and that soil-carbon sequestration was higher in poplar plantations compared to adjacent corn crops in south-eastern Spain [36]. Moreover, an impact on soil quality in terms of elevated carbon concentrations of a 10-year-old short rotation coppice poplar stand compared with intensive agricultural and uncultivated systems has been observed [37].

In our study, the average age of the plantations was ca. 21 years; the large majority was over 20 years old when samples were taken, and only two fields were younger than 10 years having, however, rather high standing biomass for their age. This means that most of the plantations in our study were close to the end of their growing cycle. Our results indicate that there is no evidence that poplar and hybrid aspen plantations that have grown for ca. 20 years will result in higher carbon concentrations in soil when replacing other land uses in the agricultural Swedish landscape. This result confirms studies for younger poplar plantations in other parts of the world that showed no increase in soil carbon: e.g., it was found that there was no evidence of changes in soil organic carbon in poplar plantations in the topsoil relative to adjacent agricultural soils when considered for stand ages up to 12 years [38], and the same was reported in [39] where no difference in soil carbon between poplar and other land uses (7-8 years old average age) were found. Moreover in [40], no significant changes in the topsoil in the first 15 years of poplars following afforestation of agricultural soils in China were reported. It is unclear if after some more years these poplar plantations finally indicated higher carbon concentrations in the topsoil compared to alternative land uses. It is recognized that site- 
specific factors affect the accumulation patterns of soil carbon in the topsoil, e.g., cultivation in poorer sandy soils might favor soil carbon increases in the topsoil [36, 37, 41], and the fundamental mechanisms responsible for soil organic carbon accumulation in poplar plantations are in general not well understood [19, 22, 23].

For Sweden, the maximum period that a poplar plantation can be used for energy purposes on an agricultural site is, according to the current legislation, 20 years. Judging from our results, an increase of soil carbon from bioenergy poplar plantations is unlikely to occur in Swedish topsoils following the current management practices that have been applied in the sites included in our study. At this point, it is worth mentioning again that the poplar sites included in the study represent an average situation and were by no means selected in terms of, e.g., best production figures. We also found a weak positive correlation between biomass production of poplar plantations and soil carbon in topsoil, which implies that well-managed poplar plantations resulting in high biomass production might be the key to higher carbon concentrations in topsoils.

According to our results, elevated concentrations of carbon compared to other land uses occur on the other hand in subsoil. We have found that carbon in the subsoil of poplars compared to grasslands was higher, which was rather unexpected considering the high potential of grassland to store carbon. This comes into agreement with several studies who found that soil carbon in the subsoil was higher in poplar plantations than adjacent arable land [32, 36, 42]. The concentrations of soil carbon in the subsoil in actual values are much lower than the ones in topsoil (in our case a factor of 5-8 times lower), but if such an effect is common in Swedish soils and not site-specific, then a significant impact due to soil carbon increases in deeper soil layers (with comparatively less decomposable carbon than in topsoil) can be expected where poplars are grown.

Conclusions The main conclusions of our study, in which comparisons of groundwater quality and soil carbon of a number of commercial poplar plantations with adjacent arable fields were conducted, were that:

- $\mathrm{NO}_{3}-\mathrm{N}$ leaching from poplar fields was significantly lower than that from reference fields with cereals.

- No similar observations occurred when compared with grasslands

- The differences in $\mathrm{NO}_{3}-\mathrm{N}$ leaching between poplar and reference fields were higher in spring than in autumn.

- $\mathrm{PO}_{4}-\mathrm{P}$ concentrations in the groundwater of poplars were similar compared to cereal fields, but lower compared to grassland.

- Soil carbon concentrations in the topsoil of poplar plantations were not higher than these in adjacent fields.
- For the subsoil, the average carbon concentrations in the poplar and hybrid aspen plantations were equal to the respective ones of cereals, but higher when compared to grasslands.

Acknowledgements The authors would like to thank the Swedish Energy Administration for financing this work through the project P35138-1, the Swedish Research Council Formas (project 2014-245), and Assoc. Prof. Dr. Pär Aronsson for his contributions to initiate the project. We would also like to acknowledge Richard Childs, RoseMarie Rytter, and Birger Hjelm for their help with the field work, as well as the field owners allowing us to establish the experiments. Finally, we thank Robert Hijmans and his team to make available the layers to create the maps presented in this study (www.gadm.org, version 2.8).

Open Access This article is distributed under the terms of the Creative Commons Attribution 4.0 International License (http:// creativecommons.org/licenses/by/4.0/), which permits unrestricted use, distribution, and reproduction in any medium, provided you give appropriate credit to the original author(s) and the source, provide a link to the Creative Commons license, and indicate if changes were made.

\section{References}

1. Statens Offentliga Utredningar (SOU) (2007) Bioenergi från jordbruket - en växande resurs (in Swedish) 2007:16

2. Dimitriou I, Mola-Yudego B (2017) Poplar and willow plantations on agricultural land in Sweden: area, yield, groundwater quality and soil organic carbon. For Ecol Manag 383:99-107

3. Dimitriou I, Aronsson P (2011) Wastewater and sewage sludge application to willows and poplars grown in lysimeters - plant response and treatment efficiency. Biomass Bioenergy 35(1):161-170

4. Weih M, Nordh N-E (2005) Determinants of biomass production in hybrid willows and prediction of field performance from pot studies. Tree Physiol 25(9):1197-1206

5. Dimitriou I, Mola-Yudego B, Aronsson P (2012) Impact of willow short rotation coppice on water quality. Bioenergy Res 5(3):537-545

6. Dimitriou I, Mola-Yudego B, Aronsson P, Eriksson J (2012) Changes in organic carbon and trace elements in the soil of willow short-rotation coppice plantations. Bioenergy R 5(3):563-572

7. González-García S, Mola-Yudego B, Dimitriou I, Aronsson P, Murphy R (2012) Environmental assessment of energy production based on long term commercial willow plantations in Sweden. Sci Total Environ 421:210-219

8. González-García S, Mola-Yudego B, Murphy R (2013) Life cycle assessment of potential energy uses for short rotation willow biomass in Sweden. Int J Life Cycle Assess 18(4):783-795

9. Schmidt-Walter P, Lamersdorf N (2012) Biomass production with willow and poplar short rotation coppices on sensitive areas- the impact on nitrate leaching and groundwater recharge in a drinking water catchment near Hanover, Germany. Bioenergy Res 5:546-562

10. Börjesson P (1999) Environmental effects of energy crop cultivation in Sweden: identification and quantification. Biomass Bioenergy 16:137-154

11. Werner A, McCracken A (2008) The use of short rotation coppice poplar and willow for the bioremediation of sewage effluent. Asp Appl Biol 90:317-324

12. Delgado A, Scalenghe R (2008) Aspects of phosphorus transfer from soils in Europe. You have full text access to this content. J Plant Nutr Soil Sci 171:552-575 
13. Djodjic F, Borling K, Bergstrom L (2005) Phosphorus leaching in relation to soil type and soil phosphorus content. J Environ Qual 33(2):678-684

14. Don A, Osborne B, Hastings A, Skiba U, Carter MS, Drewer J, Flessa H, Freibauer A, Hyvonen N, Jones MB, Lanigan GJ, Mander U, Monti A, Djomo SN, Valentine J, Walter K, Zegada-Lizarazu W, Zenone $\mathrm{T}$ (2012) Land-use change to bioenergy production in Europe: implications for the greenhouse gas balance and soil carbon. Glob Change Biol Bioenergy 4:372-391

15. Hansen EA (1993) Soil carbon sequestration beneath hybrid poplar plantations in the north central United States. Biomass Bioenergy 5: 431-436

16. Makeschin F (1994) Effects of energy forestry on soils. Biomass Bioenergy 6:63-79

17. Kahle P, Hildebrand E, Baum C, Boelcke B (2007) Long-term effects of short rotation forestry with willows and poplar on soil properties. Arch Agron Soil Sci 53:673-682

18. Rytter RM (2012) The potential of willow and poplar plantations as carbon sinks in Sweden. Biomass Bioenergy 36:86-95

19. Crow P, Houston TJ (2004) The influence of soil and coppice cycle on the rooting habit of short rotation poplar and willow coppice. Biomass Bioenergy 26(6):497-505

20. Qin ZC, Dunn JB, Kwon HY, Mueller S, Wander MM (2016) Soil carbon sequestration and land use change associated with biofuel production: empirical evidence. Glob Change Biol Bioenergy 8(1):66-80

21. Walter K, Don A, Flessa H (2015) No general soil carbon sequestration under central European short rotation coppices. Glob Change Biol Bioenergy 7(4):727-740

22. Garten CT, Wullschleger SD, Classen AT (2011) Review and model-based analysis of factors influencing soil carbon sequestration under hybrid poplar. Biomass Bioenergy 35(1):214-226

23. Jug A, Hofmann-Schielle C, Makeschin F, Rehfuess KE (1999) Short-rotation plantations of balsam poplars, aspen and willows on former arable land in the Federal Republic of Germany III. Soil ecological effects. For Ecol Manag 121:85-99

24. Pinheiro J, Bates D, DebRoy S, Sarkar D, R Core Team (2015). nlme: Linear and nonlinear mixed effects models. $\mathrm{R}$ package version 3.1-131

25. Bates D, Maechler M, Bolker B, Walker S (2015) Fitting linear mixed-effects models using lme4. J Stat Softw 67(1):1-48

26. Dimitriou I, Mola-Yudego B (2017) Nitrogen fertilization of poplar plantations on agricultural land: effects on diameter increments and leaching. Scand J For Res. doi:10.1080/02827581.2016.1264622

27. Johansson T, Karačić A (2011) Increment and biomass in hybrid poplar and some practical implications. Biomass Bioenergy 35: $1925-1934$

28. Karacic A (2005) Production and ecological aspects of short rotation poplars in Sweden. 2005(13)
29. Swedish Board of Agriculture (2009) Riktlinjer för gödsling och kalkning 2010. Jordbruksinformation 13-2009. Jordbruksverket pp 23-53

30. R Development Core Team (2015) R: a language and environment for statistical computing. R Foundation for Statistical Computing, Vienna

31. Hjelm B, Mola-Yudego B, Dimitriou I, Johansson T (2015) Diameter-height models for fast-growing poplar plantations on agricultural land in Sweden. BioEnergy Res 8:1759-1768

32. Syswerda SP, Basso B, Hamilton SK, Tausig JB, Robertson GP (2012) Long-term nitrate loss along an agricultural intensity gradient in the Upper Midwest USA. Agric Ecosyst Environ 149:10-19

33. Aronsson PG, Bergström LF (2001) Nitrate leaching from lysimetergrown short-rotation willow coppice in relation to $\mathrm{N}$ application, irrigation and soil type. Biomass Bioenergy 21(3):155-164

34. Djodjic F, Bergström L (2005) Phosphorus losses from arable fields in Sweden - effects of field-specific factors and long-term trends. Environ Monit Assess 102(1-3):103-117

35. Ulen B, Bechmann M, Folster J, Jarvie HP, Tunney H (2007) Agriculture as a phosphorus source for eutrophication in the north-west European countries, Norway, Sweden, United Kingdom and Ireland: a review. Soil Use Manag 23(1):5-15

36. Sierra M, Martınez FJ, Verde R, Martın FJ, Macıas F (2013) Soilcarbon sequestration and soil-carbon fractions, comparison between poplar plantations and corn crops in south-eastern Spain. Soil Tillage Res 130:1-6

37. Pellegrino E, Di Bene C, Tozzini C, Bonari E (2011) Impact on soil quality of a 10-year-old short-rotation coppice poplar stand compared with intensive agricultural and uncultivated systems in a Mediterranean area. Agric Ecosyst Environ 140(1-2):245-254

38. Coleman MD, Isebrands JG, Tolsted DN, Tolbert VR (2004) Comparing soil carbon of short rotation poplar plantations with agricultural crops and woodlots in North Central United States. Environ Manag 33:299-308

39. Grigal DF, Berguson WE (1998) Soil carbon changes associated with short-rotation systems. Biomass Bioenergy 14:371-377

40. Mao R, Zeng DH (2010) Changes in soil particulate organic matter, microbial biomass, and activity following afforestation of marginal agricultural lands in a semi-arid area of Northeast China. Environ Manag 46(1):110-116

41. Hellebrand HJ, Strahle M, Scholz V, Kern J (2010) Soil carbon, soil nitrate, and soil emissions of nitrous oxide during cultivation of energy crops. Nutr Cycl Agrosyst 87(2):175-186

42. Kostyanovsky KI, Evanylo GK, Lasley KK, Daniels WL, Shang C (2011) Leaching potential and forms of phosphorus in deep row applied biosolids underlying hybrid poplar. Ecol Eng 37(11): $1765-1771$ 